\title{
STRATEGI PENGEMBANGAN PROGRAM STUDI PENDIDIKAN AGAMA ISLAM DI PERGURUAN TINGGI ISLAM
}

\author{
Muhammad Hanif \\ Fakultas Agama Islam Universitas Islam Malang \\ muhammad.hanif@unisma.ac.id
}

Diterima: 4 Oktober 2019 | Direvisi: 15 Oktober 2019 | Disetujui: 11 November 2019

(C) 2018 Program Studi Pendidikan Agama Islam Fakultas Agama Islam Universitas Islam Malang

\begin{abstract}
The current of globalization has affected many sectors including tertiary institutions. This scientific work reveals the strategy of study programs in higher education in order to develop continuously to improve management development in accordance with the needs and challenges that come. In this article, two important aspects that need to be considered are human resources and curriculum that are relevant to the conditions of globalization. While researchers obtain data based on literature research that has been done.
\end{abstract}

Keyword: Strategy, Development, PAI Study Program

\begin{abstract}
Abstrak
Arus globalisasi telah mempengaruhi banyak sektor termasuk lembaga pendidikan tinggi. Karya ilmiah ini mengungkap strategi program studi pada pendidikan tinggi agar dapat berkembang secara terus menerus melakukan improvisasi pengembangan manajemen sesuai dengan kebutuhan dan tantangan yang dating. Pada artikel ini diungkap tentang dua aspek penting yang perlu diperhatikan yakni sumber daya manusia dan kurikulum yang relevan dengan kondisi globalisasi. Sementara peneliti memperoleh data berdasarkan penelitian literature yang telah dilakukan.
\end{abstract}

Kata Kunci: Strategi, Pengembangan, Program Studi PAI

\section{Pendahuluan}

Kita hidup di zaman yang terus berubah menuju kehidupan yang lebih nyaman. Di awal millennium ketiga ini, perubahan dan perkembangan di segala aspek kehidupan telah terjadi dengan pesat. Kemajuan teknologi informasi telah mengubah kehidupan sosial masyarakat di dunia. Suatu negara sudah tidak bias lagi menutup wilayahnya dari arus informasi yang disebarkan melalui clean technology. Dampak dari munculnya teknologi ini merambah ke sistem pranata kehidupan berbangsa dan bernegara. Agenda globalisasi dengan kesepakatan AFTA tahun 2003, APEC tahun 2010, dan perdagangan bebas tahun 2020, sudah tidak bisa ditolak kehadirannya. 
Pergeseran peta politik, ekonomi, perdagangan, dan industri di tingkat global sudah tidak bisa dibendung lagi oleh suatu negara. Setiap warga negara harus siap terhadap tantangan dampak global.

Globalisasi bisa merupakan peluang, sebaliknya dapat pula menjadi lubang jurang yang dalam. Peluang bisa kita dapatkan bila kita cerdas membaca arus perubahan serta memanfaatkannya dengan sumberdaya yang terarah pengelolaannya. Sebaliknya kalau kita tidak tanggap dan kurang cerdas memanfaatkan peluang tersebut, peluang tersebut akan berubah menjadi jurang yang memperosokkan bangsa kita kelembah ketertinggalan.

Merekonstruksi kehidupan masa depan yang lebih baik menjadi tanggung jawab setiap individu. Transformasi terjadi di hampir setiap lini kehidupan, tidak saja dibidang ekonomi, social, dan budaya. Manusia yang unggul adalah manusia yang profitable, dan bukan political (Glastra ; 2004). Sementara itu, yang terjadi dinegara kita selama ini polical interest sedang in fashion, sedang ngetrend-ngetrendnya. Mengedepankan pada kepentingan politik yang dilakukan elit-elit yang sedang berkuasa, akan berdampak pada tujuan pendidikan tinggi dalam membentuk sumberdaya manusia yang memiliki tingkat national competitiveness tererosi. Semangat nasional yang kental bernuansa politik kurang memikirkan bagaimana agar bangsa maju, melainkan bagaimana suatu golongan akan dapat menang di pentas-pentas politik. Dalam setting zaman yang himperkompetitif, elit politik yang sedang berkuasa masih terpaku dengan perebutan kekuasaan dan menelantarkan pendidikan. Sementara itu sebagaian besar negara di dunia sedang berlomba menguasai pasar global, menguasai ilmu pengetahuan dan teknologi agar mampu bersaing. Untuk menjadi bangsa yang mampu berperan di percaturan global, penguasaan kemampuan professional yang tinggi serta kecerdasan cultural menjadi imperatif agar bangsa tersebut mampu berperan di zaman yang hiperkompetitif.

Kondisi seperti tersebut di depan tentunya akan mempengaruhi pula laju penyelenggaraan Pendidikan Tinggi yang terkait dengan penyiapan kualitas sumberdaya manusia (SDM). Tantangan dunia Pendidikan Tinggi di Indonesia dalam menghadapi situasi global menjadi semakin berat. Misi membentuk sumberdaya manusia yang memiliki tataran kapasitas national competitiveness untuk bersaing di era global menghadapi batu sandungan yang besar. Pendidikan belum diposisikan pada slot investasi jangka panjang. Hal tersebut tercermin pada komitmen pemerintah dalam mengalokasikan anggaran untuk pendidikan. Walau undang-undang sistem Pendidikan Nasional sudah menyebutkan angka 20\% untuk anggaran 
pendidikan namun untuk merealisasikannya masih jauh dari harapan. Anggaran untuk membiayai pendidikan masih berkisar dibawah 5\% dari anggaran negara. Bagaimana dampaknya terhadap mutu SDM kita? Ilustrasi berikut akan memperjelas kita.

Dalam hal penguasaan teknologi, Indonesia belum mampu mengolah semua sumberdaya yang dimilikinnya. Kualifikasi SDM di Indonesia kurang menggembirakan karena yang berkualifikasi lulusan perguruan tinggi hanya berjumlah 1,43\% dari jumlah penduduk Indonesia. Dari hasil survey internasional, perguruan teknologi SDM Indonesia menempati ranking 42 daru 47 negara. Di bidang manajemen peningkatan kualitas SDM, Indoneisa berada pada ranking 44, sedangkan kemampuan berkompetisi tingkst global, SDM Indonesia berada pada posisi 46 dari 47 negara di dunia.

Di samping kondisi politik terus bergejolak, kita selama ini terlena dengan arogansi sumber alam. Kekayaan alam yang melimpah meninabobokan bangsa. Padahal zaman telah berubah. Untuk berkompetisi di era global bukan lagi mengandalkan kekayaan alam yang melimpah tetapi bisa punah, melainkan penguasaan atas teknologi dan informasi, seperti yang dijelaskan oleh Porter, The country's shere of world markets for its products comes less and less from abundant natural resources, and more and more from technical innovation and creative use of technology and knowledge or the combination of both (Porter 2002). Bila kita tidak mengikuti atau menyesuaikan dengan semangat zaman tersebut, kita akan disembedded dari semangat global.

Dari ilustrasi tersebut kita bisa menyimpulkan bahwa dunia pendidikan di Indonesia menghadapi masalah yang cukup berat. Masalah menjadi semakin berat karena situasi dalam negri yang kurang menunjang. Untuk mengatasi masalah rendahnya kualifikasi SDM kita, lembaga pendidikan harus mengembangkan sistem mutu yang terarah. Sistem mutu tersebut harus dilaksanakan secara komperhensif, konsisten dan memerkulan komitmen bersama dari semua pihak yang terkait dengan dunia pendidikan baik pihak internal maupun pihak eksternal yang secara langsung maupun tidak langsung terkait dengan dunia pendidikan dan lulusannya. Dengan demikian, peningkatan mutu pendidikan bukan menjadi tanggung jawab dunia pendidikan saja, melainkan menjadi tanggung jawab bersama, pihak pemerintah, penyelenggaraan pendidikan, masyarakat, dan semua stakesholder yang terkait serta mahasiswa yang terlibat. Pihak-pihak yang terkait tersebut memiliki fungsi dan peranan sendiri-sendiri yang secara sinergis bila disatukan akan mampu mengangkat mutu pendidikan di Indonesia. Yang menjadi pertanyaan kita adalah, apakah semua pihak 
memiliki presepsi dan komitmen yang sama? Masalah akan timbul bila mereka memiliki presepsi dan komitmen yang berbeda.

\section{Metode}

Penelitian yang digunakan adalah kualitatif dengan pendekatan studi literatur. Definisi kualitatif adalah penelitian yang berlandaskan pada filsafat postpositivisme, digunakan untuk meneliti pada kondisi obyek yang alamiah (Sugiyono, 2015: 15). Penelitian kualitatif lebih diidentikkan dengan penelitian yang semua hasil datanya didiskripsikan dalam bentuk kata-kata. Namun untuk pendekatan yang digunakan adalah studi literature yang artinya melakukan pengamatan dan analisis terhadap literature maupun referensi buku yang ditulis oleh tokoh dan pakar pendidikan Islam yang kemudian dilakukan analisis secara mendalam.

Selain itu dalam pengumpulan data tidak hanya dilakukan melalui observasi tetapi juga menggunakan dokumentasi tertulis yang diolah dalam bentuk analisis hasil observasi yang dilakukan peneliti. Disamping itu, peneliti melakukan wawancara sebagai tambahan dalam mempertajam data yang diperoleh dengan menggunakan dua teknik di atas. Namun wawancara dilakukan secara tidak terstruktur melalu pengajuan pertanyaan yang dilontarkan kepada tokoh pendidikan Islam dengan melalui diskusi dan Tanya jawab. Adapun teknik analisisnya melalui tahapan diplai data, reduksi data dan penarikan kesimpulan.

\section{Pembahasan}

\section{Membangun Strategi Pengembangan Perguruan Tinggi}

Strategi adalah sebuah rencana yang komperhensif yang mengintegrasikan segala resources dan capabilities yang mempunyai tujuan jangka panjang untuk mencapai suatu tujuan yang diharapkan. Perguruan tinggi dapat bergerak dengan cepat sekaligus benar, manakala adanya kemampuan untuk menentukan posisi baru dengan paradigm dan orientasi baru pula yang disebut dengan repositioning. Reposisi Perguruan Tinggi dilaksanakan dengan menilai dan mereview seluruh kekuatan dan kelemahan sehingga dapat menentukan mana yang harus diperbaiki dan mana yang harus diperkuat.

Strategi pengembangan ini amatlah penting bagi perguruan tinggi, karena merupakan salah satu bentuk dari public and social accountability universitas. Dalam membangun sarana fisik, secara ideal perguruan tinggi harus memenuhi kebutuhan sarana-prasarana yang representative dan modern. Fasilitas yang demikian harus dilengkapi dengan daya dukung pengembangan keilmuan yang dibutuhkan seperti; multimedia, monitoring 
system for learning processes, wifi, dll. Selain itu juga secara berimbang harus memiliki dosen yang memedahi, baik dari sisi kuantitas maupun kualitas.

Ada beberapa strategi, yang digunakan untuk mengembangkan perguruan tinggi. Dalam Minisrty of National Education Republic of Indonesia; Long Trem Strategy 2003-2010, salah satu strategi yang harus dilakukan adalah membangun kesehatan organisasi, yang meliputi:

a. Membangun Kapasitas Institusional

Merespon terhadap perubahan paradigm dalam konteks otonomi dan desentralisasi, institusi harus secara konsisten memperbaiki kapasitas institusional mereka memastikan kualitas diluar standar khusus. Artinya bahwa institusi perguruan tinggi hendaknya terpacu untuk terus melakukan pembenahan kapasitas kelembagaannya baik dari aspek internal maupun eksternal. Aspek internal yang dimaksud adalah adanya upaya yang sistematis untuk meningkatkan kualitas sumberdaya manusia, kaderisasi, dan sekaligus ketersediaan fasilitas yang diperlukan. Kaderisasi yaitu menyiapkan personel sebagai estafet kepemimpinan institusi dalam melanjutkan pencapaian dari tujuan yang diharapkan. Sedangkan aspek eksternal adalah menjalin kerjasama atau bermitra dengan pihak lain dalam membangun networking guna mendorong keberhasilan tujuan institusi yang di harapkan.

b. University Governance

Sebuah sistem governance yang baik kontingen terhadap tujuan institusi pendidikan tinggi dan nilai sosial yang membentuknya. Oleh karena itu, kebijakan institusi individual untuk menentukan governance harus memperhatikan hal tersebut. Good governance harus mendorong kebebasan akademisi yang mengakui akuntansi akademisi untuk mendefinisikan area penelitian mereka sendiri, mengajar, dan mempublikasikan. Dalam lingkup desentralisasi sistem pendidikan tinggi, sistem governance memungkinkan fakultas/program studi dan administrator untuk menyampaikan suara dalam menentukan kebijakan institusional. Manajeman puncak institusioal harus sepenuhnya dilakuna dalam proses pengembangan perencanaan strategis, termasuk keterlibatan (partisipasi) komunitas internal dan stakeholder. Lagipula, manajemen level puncak harus memastikan bahwa perencanaan steategis akan digunakan sebagai refrensi oleh seluruh level manajemen. Agar mempunyai perencanaan strategis yang berhubungan secara organisasional dengan perencanaan operasional, maka perlu adanya 
kesadaran personal terhadap tugas serta adanya pendelegsian otoritas yang tepat.

c. Keuangan

Pendidikan tinggi di Indonesia dianggap kekurangan dana dibandingkan dengan negara-negara berkembang di Asia, apalagi bagi perguruan tinggi swasta. Ada juga perdebatan tanpa akhir tentang apakah pendidikan tinggi adalah barang public ataukah pribadi. Oleh karena itu, sebuah trend menarik dalam peningkatan partisipasi komunitas adalah dalam pendanaan pendidikan tinggi melalui fee, donasi pribadi, kolaborasi universitas industri, dan keterlibatan pemerintah pusat maupun lokal. Kontribusi yang diberikan sepanjang tidak bertentangan dengan norma dan nilai akademis. Seiring dengan semangat otonomi, baik regional maupun lokal mempunyai kapasitas lebih kuat untuk mendukung sektor pendidikan termasuk pendidikan tersier.

Dalam pengembangannya, perguruan tinggi dan keuangan merupakan satu kesatuan yang tidak dapat dipisahkan. Sistem keuangan di perguruan tinggi harus lebih diorientasikan pada kegiatan-kegiatan produktif sebagai penopang operasional industri, dan tidak hanya bersumber dari iuran mahasiswa.

d. Sumberdaya manusia

Temuan yang diperoleh sejauh ini menunjukkan secara jelas bahwa sebagaian besar institusi pendidikan tinggi, khususnya pada sektor public, pada saat bersamaan terdapat kelemahan dan kekurangan staf. Ada yang kelebihan staf, namun dalam pengertian kuantitas, dan kekurangan staf dalam pengertian kualitas.

Dalam sektor perguruan tinggi misalnya, isu utama dalam sumberdaya manusia adalah menangani kualitas dosen yang kurang memadai. Dalam pengertian kuantitas, problem yang paling penting adalah terlalu bergantung kepada pegawai/dosen paruh waktu, yang sebagaian besar merupakan staf institusi public yang lainnya. Sehingga komitmen untuk menggembakan institusi tersebut juga tidak sepenuhnya dapat dilakukan.

Selain itu, sivitas akademika perguruan tinggi harus berani mengikrarkan dirinya bahwa kampus tidak hanya sebagai tempat transformasi ilmu dari pihak dosen kepada mahasiswa yang berlangsung secara formal dan mekanis sifatnya, begitupula tidak hanya sekedar menyelenggarakan ujian-ujian untuk memperoleh sertifikat dan tanda lunas. Melainkan lebih dari itu ingin menjadikan dirinya benar-benar 
sebagai "Wahana Ilmu". Yakni sebagai wahana ilmu penghuninya yang selalu memiliki ciri khas mengedepankan keberanian yang bertanggung jawab, kebebasan yang didasari kekuatan nalar yang kuat serta keterbukaan dalam menerima segala informasi keilmuan yang diperlukan.

e. Jaminan Kualitas

Pengertian jaminan kualitas (Quality Assurance:QA) mulai masuk pada istilah pendidikan lebih dari sepuluh tahun yang lalu, proses ini menyediakan organisasi dengan akreditasi untuk mengukur kualitas pada bidang pendidikan dan kesehatan. Pada negara-negara yang telah maju, quality assurance juga telah diimplementasikan dalam pendidikan, dimana quality assurance dapat dilihat sebagai bentuk akuntabilitas untuk standar professional.

Perbaikan kualitas kintinyu seharusnya menjadi perhatian utama. Jaminan kualitas seharusnya dikendalikan secara internal, diinstitusionalisasi di dalam masing-masing prosedur standar organisasional dan juga harusnya melibatkan pihak eksternal. Namun demikian, karena kualitas juga berhubungan dengan seluruh stakeholder, perbaikan kualitas seharusnya menghasilkan output dan outcome kualitas sebagai bagaian dari akuntabilitas publik.

Untuk itu, disetiap perguruan tinggi sudah seharusnya mempunyai sebuah lembaga penjamin mutu terhadap kualitas input, procces, output dan outcome. Dengan ada lembaga penjaminan mutu tersebut dibidang akademik, karyawan, layanan, keuangan, dan kesesuaian antara produk akademik yang dihasilkan oleh perguruan tinggi dengan stakeholder, akan menumbuhkembangkan rasa saling percaya dan membangun image perguruan tinggi yang baik di masyarakat. Apabila masyarakat merasa puas, maka akan terjalin keterikatan secara emosional dan secara bertahap akan mengembangkan loyalitas pada Perguruan Tinggi.

\section{Mengembangkan Kurikulum Perguruan Tinggi Islam}

Pengembangan kurikulum yang dimaksud adalah berbasiskan kompetensi yang bertolak dari landasan filosofis, bahwa manusia memiliki potensi jismiah, nafsiyah yang mengandung dimensi al-nafsu, al-'aql dan al$q a l b$, serta potensi ruhiyah yang memancar dari dimensi al-ruh dan al-fitrah. Sehingga manusia siap mengadakan hubungan vertical dengan Tuhannya (habl min Allah) sebagai manifestasi dari sikap teosentris manusia yang mengakui Ketuhanan Yang Maha Esa. Dan manusia yang diciptakan adalah manusia yang mampu mengemban tugas-tugasnya di muka bumi, baik sebagai hamba Allah maupun khalifahNya. 
Dalam mewujudkan fungsi-fungsi kekhilafahannya, menurut Muhaimin (2005), maka seseorang harus: (1) memiliki ilmu pengetahuan dan keterampilan; (2) bisa melaksanakan tugas/pekerjaan sesuai dengan ilmu keterampilan yang dimiliki; (3) bisa menemukan jati dirinya sebagai apa atau siapa dirinya itu; (4) bisa bekerjasama dengan orang lain dan berbuat sesuatu yang bermanfaat bagi pihak lain.

Fungsi-fungsi kekhilafahan tersebut di atas harus di lakukan mengingat dalam prespektif sosiologis bahwa masyarakat Indonesia bersifat plural, serba ganda dan beragam, sehingga tidak adil bila segala-galanya harus disamakan. Karena itu, pengembangan kurikulum harus memberikan peluang bagi masing-masing perguruan tinggi islam untuk berimprovisasi dan berkreasi dalam mengembangkan pendidikan sesuai dengan kemampuan dan kebutuhannya. Disamping itu masyarakat bersifat dinamis dan berkembang, sehingga memerlukan kemampuan untuk beradaptasi dan atau kesiapan untuk berhadapan dengan dinamika perubahan dan perkembangan yang ada.

Untuk itu, prinsip-prinsip dasar kurikulum berbasis kompetensi, yang harus diperhatikan, antara lain : (1) menekankan pada hasil (out come); (2) out come merupakan kompetensi yang diukur; (3) evaluasi keberhasilan merupakan pengukuran kekuasaan kompetensi yang telah di capai (competensi mastery) oleh peserta didik; (4) revalansi lebih besar pada pekerjaan dan tugas-tugas nyata dan dunia kerja; dan (5) menekankan kemampuan berfikir lebih tinggi. Kelima prinsip tersebut menjadi dasar pijakan dalam proses pengembangan kurikulum

Dari prinsip-prinsip diatas, pengembangan kurikulum perguruan tinggi Islam harus di dasari atas, (1) pembelajaran yang dapat mengantarkan peserta didik/mahasiswa dari pengetahuan agama yang kognitif menjadi makna dan nilai (afektif, psikomotorik) untuk diinternalisasikan dalam diri peserta didik/mahasiswa, (2) kolaborasi antara program-program pendidikan non-agama dengan agama, dan (3) relevansi terhadap perubahan sosial atau mengilustrasikan konteks sosial budaya.

\section{Kesimpulan}

Di era Globalisasi seperti sekarang ini, perguruan tinggi menghadapi tantangan yang tidak mudah, baik mempertahankan institusi maupun menjaga kualitas pendidikannya dan yang tetap memegang teguh konsistensi untuk terus membangun dan melakukan konsolidasi ideal baik struktural maupun personal. Ideal yang dimaksud yaitu berupa pembentukan tekad, wawasan dan kesepakatan secara terpadu akan makna perjuangan dalam lembaga pendidikan tinggi. Hal ini sangan menentukan 
terhadap sistem maupun cara pengelolaan dan pengembangan masa mendatang, yaitu profesionalisme.

Struktural yang dimaksud adalah pelaksanaan organisasi yang harus terus dilakukan improvisasi. Walaupun pelaksanaannya ada beberapa hal yang agak menyimpang dari kaidah penyelenggaraan perguruan tinggi. Kebijakan ini ditempuh untuk memperoleh efisiensi dan efektifitas yang sesuai dengan kondisi dan kemampuan yang dimiliki oleh institusi serta disiplin keilmuan yang di kembangkan.

Sedangkan personal, adalah adanya kesiapan regenerasi untuk menyiapkan penggantian pimpinan dan pembinaan di siplin kerja, baik di tingkat perguruan tinggi maupun fakultas yang dilakukan secara periodik. Dengan kinerja sivitas akademika yang baik, prestasi di bidang penelitian dan akademik yang baik, tersedianya fasilitas pendukung yang memadai serta ditopang manajemen yang baik akan mengantarkan pergutuan tinggi yang ideal dan diidamkan oleh banyaj kalangan.

\section{Daftar Rujukan}

Ahmad Sonhaji KH, 1992, Hubungan Simbolik Antara Perguruan Tinggi dan Industrialisasi: Implikasi Terhadap Pengelolaanya (Pidato Ilmiah Disampaikan dalam Rangka Dies Natalis ke-38 IKIP Malang Pada Tanggal 16 Oktober 1992).

Balitbang Depdiknas, 2006.

David Warner and David Palfreyman (Ed), 1996, Higher Education Management, the Sosiety for Research into Higher Education and Open University Press.

Gill Robinson Hickman (Ed), 1998, Leading Organization; Prespectives For A New Era, SAGE Publication, Thousand Oaks London, New Delhi.

Imam Suprayogo, 2004, Pendidikan Berparadikma Al-Qur'an; Pergulatan Membangun Tradisi dan Aksi Pendidikan Islam, UIN Press, Malang.

James W. Smither, 1998, Performance Appraisal; State of The Art in Practice, Josse-Bass Publishers, San Fransisco.

Muhaimin, 2005, Pengembangan Kurikulum Pendidikan Agama Islam di Sekolah, madrasah dan Perguruan Tinggi, PT.Rajawali Pers, Jakarta.

Satryo Soemantri Brodjonegoro, 2003, Ministry of National Education Republic of Indonesia; Long Term Strategy 2003-2010. 